Nicholas Catasso 7

Journal of Universal Language 12-1

March 2011, 7-46

\title{
The Grammaticalization of Demonstratives: A Comparative Analysis
}

\author{
Nicholas Catasso \\ Università Ca' Foscari di Venezia
}

\begin{abstract}
An article, irrespective of its distribution across natural languages, dialects and varieties, is a member of the class of determiners which particularizes a noun according to language-specific principles of grammatical and semantic structuring. Definite articles in IndoEuropean languages - in those grammatical systems where they are present - are derived from ancient demonstratives through a grammaticalization process: given that demonstratives are deictic expressions (i.e. they depend on a frame of reference which is external to that of the speaker and of the interlocutor) with the role of selecting a referent or a set of referents, it is easy to understand what the role of "universal quantifier" of the, which is in English the prototypical - but questionable - example of definiteness, is due to. Demonstratives are frequently reanalyzed across languages as grammatical markers (very often as definite articles, but also as copulas, relative and third person pronouns, sentence connectives,
\end{abstract}

\footnotetext{
Nicholas Catasso

Dipartimento di Scienze del Linguaggio - Dorsoduro 3462 - VENEZIA 30123 (VE)

Phone 0039-3463157243; Email: nicholas_catasso@libero.it

Received Oct. 2010; Reviewed Dec. 2010; Revised version received Jan. 2011.
} 
focus markers, etc.). In this article I concentrate on the grammaticalization of the definite article in English, adopting a comparative-contrastive approach (including a wide range of IndoEuropean languages), given the complexity of the article.

Keywords: grammaticalization, definite articles, English, IndoEuropean languages, definiteness

\section{Introduction}

In this paper, I investigate the incidence of the grammaticalization of demonstratives into articles from a comparative perspective, arguing that a correlation between the diachronic development of deictic expressions and that of the pragmatic-semantic concept of definiteness is definitely present. I took into account not only the typological - and therefore statistical - tendency of demonstratives to lose a [+demonstrative] (Lyons 1999) or [+deictic] (Giusti 2001) feature and become definite noun determiners (whatever may be intended as "definiteness") in the majority of Indo-European languages, but also a number of considerations which can be drawn from the observation of languages in synchrony.

First of all, in order to understand this process, which I argue is ultimately attributable to the context factor ${ }^{1}$, we need to categorically

\footnotetext{
${ }^{1}$ According to Traugott's definition, grammaticalization in general can be considered as "the process whereby lexical material in highly constrained pragmatic and morphosyntactic contexts is assigned grammatical function and, once grammatical, is assigned increasingly grammatical, operator-like function". Meillet (1912) anticipated this concept of pragmatics - and its decisive nature over the whole process - by introducing the importance of "expressivity" (which he intended more or less as semantics, pragmatics) in the domain of grammaticalization. He notes, for example, that in Latin the role of word order was "expressive", not grammatical. A sentence can be rendered through different word orders: Catullus amat Lesbiam, Lesbiam amat Catullus, Amat Catullus Lesbiam, Amat Lesbiam Catullus, and so forth. The fixing of word order has a grammatical function and bears at least two of the main features of grammaticalization: firstly, it does not
} 
discriminate (purely) grammatical versus lexical items. This distinction is basic in morphology for the semantic categorization of morphemes bearing either lexical or grammatical meaning. According to their function, open word classes, i.e. lexical items, normally include adjectives, verbs (excluding auxiliary verbs), nouns, prepositions $^{2}$ - used to report or describe qualities and actions; on the other hand, closed word classes - indicating relationships and definiteness/indefiniteness, linking parts of the discourse, etc. - are composed of finite sets of words and are more reluctant to the addition of new members, although they may undergo phonetic modifications over long periods of time. Generally speaking, though, a form can be said to be "grammaticalized" when, having a content word as a starting point, it develops and assumes the grammatical features of a function word. Considering that in most languages not all function words are phonologically and syntactically independent, it is possible to discriminate grammatical forms that display a more labile bonding with other grammatical units from forms which imply a less loose relationship (e.g., affixes, which are attached to a stem to form a new word). In particular Hammond and Noonan 1988 in Theoretical Morphology: Approaches in Modern Linguistics speak of a "continuum of bonding" characterized by a set of variability from one form to another. The focal areas are, in order of bonding:

a) Prepositions bearing locative meaning with a full segmental and prosodic structure such as in This is the city I would love to live in, which show to have no reductions of any kind and are fully stressed (in this

modify existent grammatical tools, but creates new ones; in the second place, it implies a development from expressive to grammatical meaning.

2 The status of prepositions as contentives or as functors is problematic in current syntactic theory (for an exhaustive discussion of the topic and its variants see Cruttenden/Faber 1991) 
10 The Grammaticalization of Demonstratives: A Comparative Analysis

case, the full preposition is absolutely independent);

b) Derivational morphemes adding a meaning component (which are, therefore, neither inflections nor clitics) and affecting or not the category in question ${ }^{3}$. Classical examples are the prefix $r e-$, indicating repetition, and the suffix $-e r$, deriving a noun from a verb and in particular designating persons from objects of their labour or occupation. Since derivational affixes are bound morphemes, they basically differ from compounds in that free morphemes are used in that case to form new words;

c) Clitics, which differ from affixes in a number of linguistic features (though they must appear next to their host, i.e. an autonomous word), as Anderson (2006: 33) notes: they have a lower degree of selection with respect to their hosts; they are less likely to have idiosyncratic shapes and semantics as compared to affixed units; differently from affixes, they can be attached to material already containing clitics. From a certain point of view, clitics may be considered as being halfway between autonomous words and affixes, as they share particular features, e.g. the fact that they form an accentual unit with the host;

d) Inflections are endings that carry grammatical information such as tense and number (e.g. the French singular/ plural contrast la maison - les maisons).

In the second place, it is of fundamental importance to determine the nature of definiteness. Lyons (1997) argues that what we call

\footnotetext{
${ }^{3}$ While suffixes frequently affect the category of the item (for instance, Eng. -ly derives adverbs from adjectives), prefixes rarely do: for example en- forms verbs from nouns and adjectives (enlarge, encircle, etc.).
} 
"definite articles" need not be associated with a particular [+definite] feature: definiteness is not necessarily realized in lexical form (for instance by a definite item) but it is rather grammaticalized structurally through the specifier of the functional projection D, whatever may occupy this position in any given occasion. Although I support Lyons' basic assumption that definite articles are not necessarily the only source of definiteness in the NP structure, I argue here that NPs bear a feature which could be defined as "force of the NP" (henceforth FNP), occupying a higher functional projection and determining the grade of definiteness of the nominal expression on the basis of the context. Arguing for an application of the "Force" concept to the NP structure, I refer to the notion introduced by Rizzi (1997) in his analysis of the left periphery of the English sentence, i.e. the conclusion that the $\mathrm{C}$ system involves a structure of the type FORCE - (TOP*) - FOC - (TOP*) - FIN - IP. Given the structure of the split CP, I argue for a symmetrization of $\mathrm{CP}$ and NP, assuming the same deep representation. I propose that NPs are inherently definite (one consideration which is generally related to proper names) and this "[+definite $]$ feature" is licensed or not by the context. Definite articles - and other determiners - are generated in the functional projection D and move then to FNP to receive the definite feature they are interpreted with. I agree with Giusti (1997: 103-105) that the definite article has no semantic content but only encodes structural case, i.e. it corresponds to the morphological case which Indo-European languages have been losing in the course of their diachronic development. What is more, for the Balkan languages displaying a postponed determiner (e.g. Romanian, Macedonian, Bulgarian) the same structure can be assumed:

Eng. $\left[\mathrm{FNP}\left[\mathrm{FN}^{\prime}\left[\mathrm{FN}^{\circ}\right.\right.\right.$ thei $\left[\mathrm{DP}\left[\mathrm{D}^{\prime}\left[\mathrm{D}^{\circ} \mathrm{ti}\left[\mathrm{NP}\left[\mathrm{N}^{\prime}\left[\mathrm{N}^{\circ}\right.\right.\right.\right.\right.\right.$ flowers $\left.\left.\left.\left.\left.\left.\left.\left.]\right]\right]\right]\right]\right]\right]\right]\right]$ Rom. [FNP floare-jFN'[FN $\left.\left.\left.{ }^{\circ}-\mathrm{le}_{i}\left[\mathrm{DP}\left[\mathrm{D}^{\prime}\left[\mathrm{D}^{\circ} \mathrm{ti}\left[\mathrm{NP}\left[\mathrm{N}^{\prime}\left[\mathrm{N}^{\circ} \mathrm{tj}\right]\right]\right]\right]\right]\right]\right]\right]\right]$ 
In the absence of a context which allows a definite interpretation for the NP, the phrase remains undefined (i.e. articleless in the languages which display an article system) or receives an indefinite interpretation (*She ate pear vs. She ate the pear vs. She ate a pear).

\section{The Question of the Origin of the Category "Article"}

An article - regardless of its distribution across languages, varieties or dialects - is a member of the class of determiners that restricts or particularizes a noun indicating the type of reference made by it, with very peculiar uses which in usage are to be considered language-specific.

In my analysis I will focus on the origin and development of definite articles in Indo-European languages - in those grammatical systems where they are present - which derive from ancient demonstratives. Considering that demonstratives are deictic expressions (i.e. they depend on a frame of reference which is external to that of the speaker and the interlocutor) which serve to select a referent or a set of referents, it is easy to understand what the character of universal quantifier of such an article as "the", which is the prototypical example of definiteness in English, is due to. As pointed out by Diessel (2008: 12), demonstratives are frequently reanalyzed across languages as grammatical markers (very often as definite articles, as in the case considered here, but also as copulas, relative and third person pronouns, focus markers, sentence connectives, etc.). I will concentrate in particular on English and German as representatives of the Germanic language family preferring, nevertheless, a comparative and contrastive perspective on the topic, given the complexity and variability of the issue.

The question of the origin of demonstratives has been the subject of much interest in the grammaticalization research, although it has 
not been entirely resolved. Demonstratives are generally considered to be grammatical items and the grammaticalization theory claims that all grammatical development involves shifts in specific linguistic contexts from a $[+$ lexical $]$ to a $[+$ grammatical $]$ item ${ }^{4}$, but there is "no evidence from any language that demonstratives derive from a lexical source or any other source, for that matter, that is nondeictic" (Diessel 1999: 44; also cf. Himmelmann 1997: 21). Traugott (1982: 245) says, for example: "It is dubious whether we can trace all grammatical markers derived by processes of grammaticalization to lexical items rather than to certain seemingly fundamental grammatical items, such as demonstratives pronouns and interrogatives. The Indo-European $t$ - demonstrative and $k U$-interrogative, for example, have been remarkably resistant to change over several thousand years, and no lexical source seems recontructable for them".

Next to the classical interpretations of the definite article as a determiner with two main functions (that of particularizing or of specifying as in "The apple that I have eaten" and that of generalizing as in "The dog is the man's best friend"), there are a number of interesting views, starting from Lyon's (1999: 290), who defines the function of articles as similar to that of expletive subjects. For Giusti (1997: 103-105) the article has no semantic content (like definiteness, for instance), but only encodes structural case. In this sense, she analyzes the functional projection containing NPs "not as a Determiner Phrase (DP), but rather as a Functional Projection (FP), whose head $\mathrm{F}^{\circ}$ is reserved for nominal case and articles".

It is interesting to notice that, even though in Indo-European no traces of definite or indefinite article can be found and most ancient Indo-European languages lack it either, it is considered to be a typical late Indo-European feature, which appeared when the languages of this family started existing separately. In the same way

\footnotetext{
${ }^{4}$ For an exhaustive explanation of this unilateral tendency also cfr. Haspelmath's 1999 article Why is Grammaticalization Irreversible?
} 
14 The Grammaticalization of Demonstratives: A Comparative Analysis

Homer's (as well as Mycenaean) Greek had no article, but this category was already widely in use in all classical Greek dialects. This is also the case in Romance languages, although Latin had no article at all.

A general assumption of grammaticalization is that the diachronic development of definite articles is not independent of its context (i.e. of the syntactic structure it occurs in). While Lyons (1999) argues for the loss of a [+dem] feature, Giusti (2001) hypothesizes that one of the most outstanding differences between demonstratives and definite articles is the presence vs. absence of a [+deictic] feature, although both accounts crucially relate this development to the loss of a feature. ${ }^{5}$ It is compelling to consider the following hypothesis for the reanalysis of demonstratives as definite articles: instead of arguing that "there is a dependency formed between the demonstrative, which occurs in a lower functional position in the nominal structure, and the D head" (Roberts \& Roussou 2003: 136) and that this relation, which is "mediated via movement" (cf. supra), is exclusive, I propose that this diachronic interconnection should expand to comprehend a FNP node: the merger of the lexical item (i.e. the demonstrative) in D is followed by a Move $>$ Merge reanalysis in FN, in which the contextual adequacy is licensed or not licensed. As we can see in (a.) and (b.), the contextual adequacy constraint has idiosyncratic results from a semantic point of view - considering an unmarked context in which the NP has a generic value:
a. I like ${ }_{\mathrm{FNP}}\left[\varnothing_{\mathrm{DP}}\left[\mathrm{t} \mathrm{NP}_{\mathrm{NP}}[\right.\right.$ Ballett $\left.\left.]\right]\right]$
b. Amo fNP $\left[\right.$ la $_{\mathrm{DP}}\left[\mathrm{t}_{\mathrm{NP}}[\right.$ danza $\left.\left.]\right]\right]$
c. Imi place ${ }_{\mathrm{FNP}}\left[\right.$ dans- $\left._{\mathrm{UP}}[\mathrm{NP}[\mathrm{t}]]\right]$

\footnotetext{
${ }^{5}$ In particular, Lyons argues that the grammaticalization of the distal pronoun ILLE in Lat. is due to the earlier restructuring of the pronominal system, whereas Giusti relates it to the loss of morphological case marking.
} 
For Romanian, in which the article occupies a different position, we can hypothesize that the enclitic article moves from $\mathrm{D}^{\circ}$ to $\mathrm{FN}^{\circ}$, whereas the NP dans moves to [Spec, FNP] through [Spec, DP].

\subsection{Back to the Roots: the Demonstrative in PIE and in Proto-Germanic}

The history of demonstrative expressions in all modern IndoEuropean languages is extremely difficult to reconstruct. It ideally finds its origins in PIE which, as a reconstructed language, represents the abstract (methodological) limit of historical linguistics. According to the historical-comparative approach, it has been reconstructed as a language displaying among other things a complex case system. The early emergence of this particular class of linguistic expressions depends on the fact that their function is very basic in human communication ${ }^{6}$ : as Diessel (1999a: 2) notes, demonstratives orient the hearer in the speech situation, focusing his or her attention. ${ }^{7}$ The changes generally occurring with the grammaticalization of demonstratives are of two types: functional, in the sense that the grammatical items evolving from demonstratives are no longer used to focus the interlocutor's attention on entities in the outside world and they are usually deictically non-contrastive; syntactic, because logically their occurrence is often restricted to a specific syntactic context and they are obligatory to form a given grammatical structure (Diessel 1999: 2).

Beekes (1995) reconstructed a demonstrative system in IndoEuropean with only two pronouns: *so (meaning both this and that) and $* h_{1}$ (anaphoric element indicating the "just named"). PIE, as a

\footnotetext{
${ }^{6}$ Because of the basic meaning of demonstratives, it is not a case that this grammatical category constitutes one of the first to be learnt by children in L1 acquisition (Diessel, 1999a: 110). In fact, Lat. demonstrare = show, indicate.

${ }^{7}$ Also cfr. http://web.unirsm.sm/DCom/2003/Functional/Abstract/Diessel\%20handout $\% 20 \mathrm{San} \% 20$ Marino.pdf
} 
16 The Grammaticalization of Demonstratives: A Comparative Analysis

non-attested language, is naturally very difficult to reconstruct and this is particularly true for demonstrative pronouns, ${ }^{8}$ in particular because, given the many forms of demonstratives among IndoEuropean languages, the common method of comparison between these languages produces an unrealistic number of stems which make the framework confused. Here is the system proposed by Beekes, in turn based on Lane's theory (1961: 469): ${ }^{9}$

Table 1. Proximal-distal Demonstratives in Indo-European

\begin{tabular}{|c|c|c|c|c|c|c|}
\hline & \multicolumn{6}{|c|}{ Demonstrative Pronouns (Beekes) } \\
\hline & \multicolumn{3}{|c|}{ Singular } & \multicolumn{3}{|c|}{ Plural } \\
\hline & Masculine & Neuter & Feminine & Masculine & Neuter & Feminine \\
\hline Nominative & $*_{\mathrm{so}}$ & \multirow{2}{*}{$*$ tod } & $*_{\mathrm{Seh}_{2}}$ & $*$ toi & \multirow{2}{*}{$* \operatorname{teh}_{2}$} & $* \operatorname{seh}_{2} \mathrm{i} ? ?$ \\
\hline Accusative & *tóm & & $*$ teh $_{2} \mathrm{~m}$ & $*$ tons & & $*_{\text {teh }_{2} \mathrm{~ns}}$ \\
\hline Genitive & \multicolumn{2}{|c|}{$*$ (to)sio } & $*(\mathrm{t}) \operatorname{eseh}_{2} \mathrm{~S}$ & \multicolumn{2}{|c|}{$*_{\text {tesom? }}$} & *tesom? \\
\hline Ablative & \multicolumn{3}{|c|}{ *tosmōd } & \multicolumn{3}{|c|}{ *toios? } \\
\hline Dative & \multicolumn{2}{|c|}{ *tosmōi } & $*_{\text {tesieh }}$ ei & \multicolumn{2}{|c|}{ *toimus } & $*$ teh $_{2}$ mus? \\
\hline Locative & \multicolumn{2}{|c|}{ *tosmi } & $*_{\text {tesieh }_{2} \mathrm{i}}$ & \multicolumn{2}{|c|}{$*$ toisu } & $*_{\text {teh }_{2} \mathrm{su}}$ ? \\
\hline Instrumental & \multicolumn{2}{|c|}{$*$ toi? } & *toi? & \multicolumn{2}{|c|}{ *toib ${ }^{\mathrm{h}} \mathrm{i}$} & $*_{\text {teh }} \mathrm{b}^{\mathrm{h}} \mathrm{i}$ ? \\
\hline
\end{tabular}

Tracing the development of this grammatical category in the history of the English language starting from its roots in Proto- Germanic ${ }^{10}$,

\footnotetext{
${ }^{8}$ Fortson (2004), for example, reconstructed $* \mathrm{~h}_{1}$ as $* e i$-. We will adopt Beekes' view here.

${ }^{9}$ Lane elaborated a mechanism of binding a certain number of standard particles to a basic stem. The best-known example of this regards the development of the word this.

${ }^{10}$ Although the reconstruction of Proto-Germanic is difficult because of the absence of written material, researchers assume, observing the development of the attested languages, that by 250 BC Proto-Germanic had already branched into five groups of Germanic.
} 
we know that this hypothetical proto-language had a demonstrative which could serve as both a demonstrative adjective and a demonstrative pronoun.

Table 2. Anaphoric Demonstratives in Indo-European

\begin{tabular}{|c|c|c|c|c|c|c|}
\hline Nominative & $* \mathrm{~h}_{1} \mathrm{e}$ & \multirow{2}{*}{$*\left(\mathrm{~h}_{1}\right) \mathrm{id}$} & $*\left(\mathrm{~h}_{1}\right) \mathrm{ih}_{2}$ & ${ }^{*} \mathrm{~h}_{1} \mathrm{ei}$ & \multirow{2}{*}{$* \mathrm{ih}_{2}$} & $*_{\mathrm{ih}_{2}}$ es \\
\hline Accusative & $*_{\mathrm{im}}$ & & $*_{\mathrm{ih}}{ }_{2} \mathrm{~m}$ & *ins & & $*_{\mathrm{ih}}{ }_{2} \mathrm{~ns}$ \\
\hline Genitive & \multicolumn{2}{|c|}{$* \mathrm{~h}_{1}$ éso } & ${ }^{*} \mathrm{~h}_{1}$ eseh $_{2} \mathrm{~s} ?$ & \multicolumn{3}{|c|}{${ }^{*} \mathrm{~h}_{1} \mathrm{es}(\mathrm{om})$} \\
\hline Ablative & \multicolumn{3}{|c|}{$* \mathrm{~h}_{1}$ esmōd } & \multicolumn{3}{|c|}{$* \mathrm{~h}_{1} \mathrm{eios} ?$} \\
\hline Dative & \multicolumn{2}{|c|}{${ }^{*} \mathrm{~h}_{1}$ esmōi } & ${ }^{*} \mathrm{~h}_{1} \mathrm{esieh}_{2} \mathrm{ei}$ & \multicolumn{3}{|c|}{${ }^{*} \mathrm{~h}_{1}$ eimus } \\
\hline Locative & \multicolumn{2}{|c|}{$* \mathrm{~h}_{1}$ esmi } & ${ }^{*} \mathrm{~h}_{1} \mathrm{esieh}_{2} \mathrm{i}$ & \multicolumn{3}{|c|}{$* \mathrm{~h}_{1}$ eisu } \\
\hline Instrumental & \multicolumn{3}{|c|}{${ }^{*} \mathrm{~h}_{1} \mathrm{ei}$ ? } & \multicolumn{3}{|c|}{$* \mathrm{~h}_{1} \mathrm{eib}^{\mathrm{h}_{\mathrm{i}}}$} \\
\hline
\end{tabular}

Ringe (2006) has given the following paradigm, where we notice that the same s- is present in the masculine and feminine nominative singular, whereas all other forms have a p-, as in Old English:

Table 3. Demonstratives in Proto-Germanic

\begin{tabular}{|c|c|c|c|c|c|c|}
\hline & \multicolumn{2}{|c|}{ Masculine } & \multicolumn{2}{|c|}{ Feminine } & \multicolumn{2}{|c|}{ Neuter } \\
\hline & Singular & Plural & Singular & Plural & Singular & Plural \\
\hline Nominative & $*$ sa & *bai & *sō & \multirow[b]{2}{*}{ *bōz } & \multirow[b]{2}{*}{ *bat } & \multirow{2}{*}{$\begin{array}{l}{ }^{*} \text { pō, } \\
*^{*} \text { piō }\end{array}$} \\
\hline Accusative & $\begin{array}{l}* \operatorname{pen}(\overline{\mathrm{o}}), \\
* \operatorname{pan}(\overline{\mathrm{o}})\end{array}$ & *pans & *bō & & & \\
\hline Genitive & *bes(a) & *bezō & *bezōz & *baizō & - & - \\
\hline Dative & $\begin{array}{l}\text { *besmō, } \\
\text { *basmō }\end{array}$ & $\begin{array}{l}\text { *bemiz, } \\
\text { *paimiz }\end{array}$ & *pezai & *baimiz & - & - \\
\hline Instrumental & *biō & - & - & - & - & - \\
\hline Locative & ${ }^{*} \mathrm{p} \overline{\mathbf{1}}$ & - & - & - & - & - \\
\hline
\end{tabular}




\subsection{The Development in Old English and Middle English}

In Old English (approximately $7^{\text {th }}$ century- $1100^{11}$ ), which displays two types of demonstratives - the weak and the strong demonstrative pronouns -, definiteness could still be expressed through the weak and strong form of the adjective (i.e. without articles). Nevertheless, as Hogg and Denison (2008: 117) argue, some kind of article already occurred in OE prose, in association with the weak form of the adjective, to indicate definiteness. For instance, in the following example, the definite NPs are preceded by a demonstrative in combination with the weak form of an adjective - unspedigan, rican (Hogg \& Denison 2008: 117, from The Sermones Catholici, or Homilies of AElfric ${ }^{12}$ ) :

(1) Caseras he geceas ac peah he geendebyrde pone unspedigan fiscere cetforan pam rican casere

'emperors he chose and yet he ranked the unwealthy fisherman before the rich emperor'

(AECHom I, 38, 578, from: Hogg/Denison 2008: 117)

In Tables 4 and 5 we see the OE demonstratives se/pat/sēo (from which the PDE definite article "the", as well as "that" and "those" derive) and $p$ es/ $b$ is/ $/ p \bar{e} o s$ which do the same job as Modern English this/these. There is still a significant difference between the use of se/poet/sèo and the Modern English article: in the first place, unlike "the", demonstratives are (generally) not required, as (2) and (3) show; secondly, they carry more information - for example, they

\footnotetext{
${ }^{11}$ According to researchers (see, for instance, Baugh/Cable 1993), the whole period in the history of the English language from 450 to 1150 can be called "Old English", since this language was spoken by the Anglo-Saxons from the fifth century; nevertheless, the first texts in Old English, which represent the only historical source that philologists examined to study the development of the language, appeared in the seventh century.

${ }^{12}$ The Sermones Catholici, or Homilies of AElfric, Vol.1, ed. Thorpe F.S.A. (London, 1844)
} 
can express location (Van Gelderen, 2006: 59; 2000: 38):

(2) Pat hio Beowulfe $\quad . . \mid$.. medoful atbor That she-NOM Beowulf-DAT ... maedcup at-bore

'that she brought Beowulf the meadcup'

(Beowulf, vv. 623-24 $4^{13}$, from: Van Gelderen, A History of the English Language: 58)

(3) cepele cempa self mid gesíðum noble fighter-NOM self-NOM with follower-DAT PL

'The noble fighter himself with his followers' (Beowulf, vv. 1312-13, from: Van Gelderen, A History of the English Language: 59)

Table 4. Demonstratives "the", "that", "those"

\begin{tabular}{|c|c|c|c|c|}
\hline & Masculine & Neuter & Feminine & Plural \\
\hline Nominative & $\mathrm{se}$ & \multirow{2}{*}{ pæt } & sēo & \multirow{2}{*}{ bā } \\
\hline Accusative & pone & & bā & \\
\hline Genitive & \multicolumn{2}{|c|}{ pæs } & \multirow{2}{*}{ pǣre } & pāra, pǣàra \\
\hline Dative & \multicolumn{2}{|c|}{ pām } & & Pām \\
\hline Instrumental & \multicolumn{2}{|c|}{ py, pon } & & \\
\hline
\end{tabular}

Table 5. Demonstratives this", "these" in Old English

\begin{tabular}{|c|c|c|c|c|}
\hline & Masculine & Neuter & Feminine & Plural \\
\hline \hline Nominative & pes & \multirow{2}{*}{ pis } & pēos & \multirow{2}{*}{ bās } \\
\cline { 2 - 3 } Accusative & pisne & pās & \\
\hline Genitive & \multicolumn{2}{|c|}{ pisses } & \multirow{2}{*}{ pisse, pisre } & Pisra \\
\hline Dative & pissum & \multicolumn{2}{|c}{} \\
\hline Instrumental & pissum \\
\hline
\end{tabular}

\footnotetext{
${ }^{13} \mathrm{http} / / /$ www.humanities.mcmaster.ca/ beowulf/main.html
} 
20 The Grammaticalization of Demonstratives: A Comparative Analysis

Texts in this period show the use of demonstratives as well as the frequent pre-nominal position of this determiner, especially in Late Old English (Swanton 1996):

(4) ...he hoefde poet rice

'He held the kingdom, 14

(Anglo-Saxon Chronicle: Introduction, from:

Michael Swanton, The Anglo-Saxon Chronicles, London)

From ME (particularly from Late Middle English) onwards, the definite article (and later also a possessive pronoun) is the more usual option. The two demonstratives indicating number (this-these and that-those) become very frequent, as well. Both articles and demonstratives lack case distinctions (Josipovici 1971: 64):

(5) And with his fest he smoot me on the heed

'And with his fist he hit me on the head'

(Chaucer WBProl ${ }^{15}$, v. 801, from: Josipovici, The world and the book: a study of modern fiction, Stanford)

What follows is the beginning of the General Prologue from the Canterbury Tales by Geoffrey Chaucer. The text shows that the use of the definite article has become widespread (translation by Nevill Coghill):

Whan that Auerytt wt his

shoures soote,
When in April the sweet

showers fall

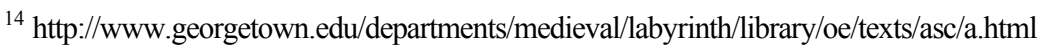

${ }^{15}$ See Chaucer, Geoffrey, The Wife of Bath's Prologue (ll.1-862), in The Canterbury Tales http://www.librarius.com/cantales.htm
} 
The droghte of March, hath perced to the roote;

And bathed euery veyne in swich lycour

Of which vertu engendred is the flour ${ }^{16}$;
And pierce the drought of

March to the root, and all

The veins are bathed in liquor

of such power

As brings about the

engendering of the flower;

Old English demonstratives could function as relatives, which is no longer the case in Middle English: that becomes the relative marker, as in the following example, from a slightly later version of Layamon:

(6) after pan flode. Dat fram God com. Dat al ere acwelde. after that flood which from God came which all here killed 'after the flood which came from God (and) which killed all (creatures) here' (Layamon's Otho 7-9) ${ }^{17}$

Table 6 shows the combinations of the definite article the and the noun sun in all numbers and cases as in Chaucer (Van Gelderen 2006: 124):

\footnotetext{
${ }^{16} \mathrm{http}: / /$ www.librarius.com/cantales.htm

${ }^{17}$ MS. Cott. Otho, C. XIII., taken from Layamon (c. 1215), Madden, Frederic, ed., Layamons Brut, or Chronicle of Britain; A Poetical Semi-Saxon Paraphrase of The Brut of Wace, I, London: The Society of Antiquaries of London, 1847: 2 (also cfr. http://etext.lib.virginia.edu/toc/modeng/public/LayBruO.html)
} 
22 The Grammaticalization of Demonstratives: A Comparative Analysis

Table 6. The Definite Article in Combination with the Noun "Sonne" in $\mathrm{ME}$

\begin{tabular}{|c|c|c|}
\hline & Singular & Plural \\
\hline \hline Nominative & the sonne & the sonnes \\
\hline Genitive & the sonnes & the sonnes \\
\hline Accusative/Dative & the sonne & the sonnes \\
\hline
\end{tabular}

\section{The Question of the Origin of the Category "Article"}

As Giusti (1993) - among others - points out, the origin of the definite article in Germanic languages coincided with the loss of morphological case. From a chronological point of view, bearing in mind that grammaticalization processes and generally speaking diachronic language change do not result in different distinct stages of a language but in a historical continuum, in late Old English there was a certain amount of syncretism in the case system of English, although it was still distinctive. The case system dramatically collapsed in the transition from $\mathrm{OE}$ to $\mathrm{ME}$. As a generally accepted explanation, the morphological loss of case in English was triggered by phonological changes (for instance, the reduction of many word-final vowels to schwa entailed that many distinctions were lost; moreover, word-final nasal consonants were eliminated). But this phenomenon has motivated in various ways depending on the theoretical framework of reference. According to another explanation (Askedal 1999 among others), the loss of morphological case was a part of the development from synthetic to analytic languages. In the generative framework this change is explained as a passage from inherent to structural case (Lightfoot 1999: 132-33). As in Table 2 and 3, Old English had four cases (nominative, genitive, accusative and dative) and a vestigial instrumental, which disappeared in the period from 
the $10^{\text {th }}$ to the $13^{\text {th }}$ century, the loss spreading through the population from the North to the South, probably under the influence of the Scandinavian settlements (O'Neil 1978). The loss of a case system generated confusion in the texts as far as case endings are concerned. Interestingly enough, some remnants of the case system still exist in English, for example in the use of pronouns (from this point of view, it will be useful to compare English and German, a language which still has a definite case system). The same goes for Romance languages, which have not preserved the Latin system:

(7) I am going to Brighton tomorrow. Would you come with me?

(8) Ich fahre morgen nach Brighton. Kommst du mit mir?

(9) (Io) vado a Brighton domain. Vieni con me?

(10) Je vais à Brighton demain. Tu viens avec moi?

Considering the system of turning NPs into arguments through morphological case, Osawa argues in his article The emergence of $D P$ in the history of English: The role of the mysterious genitive (2007: 135) that genitive lost this function earlier than the rest of the morphological case system in English: genitive-marked nouns very rarely occurred as arguments of predicates or adjectives already in Early Middle English (exception made for specific dialectal realities such as the Southern dialects where verbs like abide kept the genitive) and the genitive case came to occur almost exclusively in noun phrases. Some OE genitive nouns were replaced by "ofphrases". Philippi (1997: 65) defines the article in the modern Germanic languages - referring to its use - as a "default reference marker" and relates the development of the determiners in the Germanic languages to the loss of genitive as an object case. But following Philippi's line of inquiry - in order to understand when 
the article developed from demonstratives, it is necessary to discriminate between them and their functions, as the classification of an item in texts as either a demonstrative or an article is not always straightforward.

According to Lyons' analysis, the definite article bears the semantic feature [+Definite], whereas demonstratives are [+Definite],

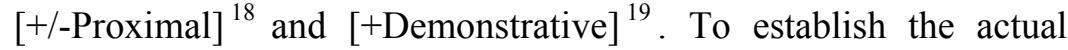
value of the demonstrative/article, syntactic evidence is much more reliable than mere form: the OED provides examples of "abnormal uses of $s e$ in oblique cases, and of $s a$ plural, ses genitive singular", specifying that in some cases "s could be a scribal error for $p$ ". Considering, therefore, syntactic rather than formal textual elements, there are basically two ways to determine the value of an item: (i) consider the number and case of its complement; (ii) consider whether or not it takes a complement. That is to say, one marker of the change is that writers started to introduce nouns other than masculine singulars with se or $p e$. Another, possibly even more important, factor is the occurrence and position of the item in the sentence. From this point of view, Giusti (2002: 50) points out that

${ }^{18}$ The definition [+/-Proximal] indicates the commonly accepted distinction between proximal demonstratives, referring to objects which are physically close to the speaker (PDE this), and distal demonstratives (PDE that), indicating objects further removed from the speaker. Italian, as well as other languages like Georgian and Spanish traditionally have a third type of demonstrative, the medial one, which basically refers to an object close to the addressee (e.g. Italian codesto/codesta).

${ }^{19}$ By "definite" we mean here, following Lyons' fundamental claim (Lyons 1999: 2), the intuitive distinction between cases like "this house" (judged by speakers as [+Definite], and "several houses" [-Definite]. Demonstratives are conceived in this framework as definite, but their definiteness is clearly "not a matter of inclusiveness". Wood (2005: 169-70) argues that demonstratives are not necessarily definite, proposing for example that in an utterance as "This man with long greasy hair and a sleeping bag sort of rolled into a ball comes over and starts looking in the bins" (BNC A74 2276) the NP "this man" is referential but not definite. 
the crucial difference between demonstratives and articles is the impossibility for the latter to appear without an overt sister projection (i.e. in order for the sentence to be grammatical, the article should be followed by a noun - further modified, by an adjective for example, or not), while this is possible with demonstratives:

\section{(11) I did this \\ (12) **I did the}

Apparent counterevidence to this generalization (Giusti, 2002: 50) can be found not only in German, but also in a number of other Germanic languages (not in English, as we have seen). I will consider German here for reasons of convenience:

(13) Ich kenne Peter. Der ist verrückt.

'I know Peter. He is crazy'

(14) Ich kenne Peter. Er ist verrückt.

'I know Peter. He is crazy'

(15) Ich kenne den, aber nicht besonders gut.

'I know him, but not particularly well'

Leiss (2007: 73) notices a significant parallelism between the (in)definiteness pattern and (im)perfectivity, claiming that the emergence of the definite article is due to changes in the aspectual system of a language, in the sense that definiteness/indefiniteness and perfectivity/imperfectivity are equivalent techniques of nominal and verbal quantification. She argues that the first occurrences of the definite article in a language are normally observable in coincidence with an erosion of the verbal part of the pattern and that there is 
26 The Grammaticalization of Demonstratives: A Comparative Analysis

converging evidence from linguistic typology that languages characterized by an article system tend to avoid aspect and aspect languages generally avoid article systems.

Interestingly, Hawkins (2004: 83-84) argues that, in principle, the commonplace of the explanation of the evolution of demonstratives into articles through the focus on the expanded semantics and pragmatics of the definite article compared with the demonstrative is basically an over-simplification: there is no reason why a category as the definite article should develop out of demonstratives, as it expresses meanings ${ }^{20}$ which are perfectly expressible in articleless languages. Such an expansion of determiners - in particular languages and in particular historical contexts - is therefore to be explained looking to the processing of grammar.

\section{Implications of the Grammaticalization of Demonstratives}

But, back to the grammaticalization process characterizing the passage from the distal demonstrative that to the definite article, interestingly enough Wood (2007: 344) assumes an analysis - in the generative framework - in which the grammaticalization of the article involves a lower specifier becoming a higher head. ${ }^{21}$ This means that the process basically consisted in "a loss of the [+Dem] feature and of the Dem > D movement" (Wood 2007: 344). Following the minimalistic perspective, she then claims that the definite article is in PDE the head of DP and is merged there. ${ }^{22}$

\footnotetext{
${ }^{20}$ The term "meaning" in this context is arguable for many linguists: Giusti (1998, among others), for instance, considers the definite article to only encode morphological case and no semantic content.

${ }^{21}$ In contrast, for example, to Lyons' hypothesis (1999: 299), who points out that determiners such as PDE the are specifiers.

${ }^{22}$ Cfr. Van Gelderen (2004), Roberts and Roussou (2003)
} 
Hopper and Traugott (2003) observe that grammaticalization involves a loss of concrete semantic content. Very interesting, from this point of view is Greenberg's argument-tation on the systematic development of the article which he conceptualizes as "the cycle of the definite article" (Greenberg 1978, 1990). Greenberg proposes three stages through which an originally deictic pronoun (whose semantics is basically referential) becomes a pure noun marker. ${ }^{23} \mathrm{He}$ speaks of the common, well-attested origin of the definite article (i.e. the demonstrative, endowed with deictic force) as the stage zero of its development. It then loses its deicticity (that is most often one which points to location near the third person rather than the first or second person) and acquires an anaphoric value (i.e. it becomes a definite article), identifying a referent as already mentioned in the previous discourse (Stage I). The second part of this development (Stage II) involves a loss of definiteness: here the article introduces noun phrases with either definite or indefinite specific reference (it has become a "non-generic article", according to Greenberg's designation). Stage III, in which the item becomes a nominal marker, is characterized by the compulsory status of the former article in any NP and is often incorporated to the noun. The general process of evolution of the demonstrative into the definite article, therefore, involves both semantic bleaching (i.e. a loss of lexical features) in that it loses any referential meaning and becomes a pure marker and a syntactic weakening, in the sense that the D element becomes an agreement morpheme and consequently undergoes syntactic decategorization.

\footnotetext{
${ }^{23}$ A noun marker is a generic category of markers which signal that a noun will follow, often bearing information about its singularity/plurality.
} 


\section{The German Case}

In German, the definite article developed from the demonstrative pronouns ther/der, thiu/diu, tha3/daz in the Old High German period. Giusti (1995: 85) confirms the view, very popular in the philological literature, according to which the loss of case marking played the most important role in the emergence of the definite article in Germanic languages, although the situation in English and in German is of course different, since English (like Dutch) has lost morphological case - with clear effects on word order - and German hasn't. A comparison between the following two texts (Tschirch 1975: 168; in Giusti 1995: 85) shows that in the 30 year time span dividing the two translations of the same Latin text by Matthew the use of the definite article seems to have completed its development. The first translation is from the Monsee fragment, dated around 800, the second from Tatian, dated around 830:

(16) a. Mt. 13,1 in illo die (Et) exiens (Jesus) de domo

b. Monsee in demo tage geng Jesus $\hat{u}$ fona hûs

c. Tatian inti ûzgangenti fon themo hûse in that day (And) going-out of the house (Jesus)

$\begin{array}{llll}\text { a. Mt. 13,1 } & \text { sedebat } & \text { secus } & \text { mare } \\ \text { b. Monsee } & \text { saz } & \text { bî } & \text { sêwe } \\ \text { c. Tatian } & \text { saz } & \text { nah themo } & \text { sêwe } \\ & \text { was sitting } & \text { near the } & \text { see }\end{array}$

While in (16) the demonstrative demo directly corresponds to the demonstrative in the Latin text, in (17) the two instances of themo do not have a counterpart in Latin and must subsequently be interpreted as articles. ${ }^{24}$ It is to be reminded, however, that the

\footnotetext{
${ }^{24}$ Tschirch (1975) notices, from this point of view: "Mit der Umfunktionierung des
} 
definite article does not make its appearance out of the blue and texts do not always show clearly the more or less established presence in all contexts of this new category; what is more, for obvious reasons the use of the new category in these stages of the languages cannot be fully compared to that of Present-Day German. Let us consider, for instance, the Lord's Prayer in two Old High German dialects, Bavarian (early $9^{\text {th }}$ century) and East Franconian (Tatian, c. 830):

Fater unser, du pist in himilum (Bavarian, Freisinger Paternoster)

Fater unser, thū thār bist in himile (East Franconian)

Vater unser, der Du bist im Himmel (Modern German)

Here, we see for example that the preposition in remains simple in both dialects, whereas in Modern German it is made up of the preposition and the article, as its relation to Himmel expresses definiteness. This is also the case in the last part of the prayer:

Uzzan kaneri unsih fona allem sunton (Bavarian, Freisinger Paternoster)

üzouh arlōsi unsih fon ubile (East Franconian) sondern erlöse uns von dem Übel (Modern German) ${ }^{25}$

Oubouzar (1992) notices that the evolution of the category "demonstrative" - which can be assumed to be in Spec-FP - into

Demonstrativs zum Artikel hat das Ahd. ein ganz einfaches Mittel entwickelt, um dem Zusammenfall der Kasus zu begegnen: die Aufgabe, die die Kasusendung einwandfrei nicht mehr zu erfullen vermag, ubernimmt der Demonstrativ, das damit zum bestimmten Artikel umgeprägt wird - der Aufgabe, die ihm das grammatische System damit zuweist, hat er sich bis heute gewachsen gezeigt!"

25 Taken from: Braune, Wilhelm, Ebbinghaus, Ernst (1994), Althochdeutsches Lesebuch, 17 th edn. Niemeyer, Paris 
30 The Grammaticalization of Demonstratives: A Comparative Analysis

the definite article in German can only be considered to be complete when the semantic relation between the determiner and $\mathrm{N}^{\prime}$ is reinterpreted as a morphological relation ${ }^{26}$.

In Middle High German and Early New High German the use of the article spreads to usage in forms which are quite similar to those of Present-Day German already from the early 1100's:

Table 7. The Definite Article in Middle High German

\begin{tabular}{|c|c|c|c|c|}
\hline & Masculine & Neuter & Feminine & Plural \\
\hline Nominative & dër & daz & diu & die/diu \\
\hline Genitive & dës & dës & dër & dër \\
\hline Dative & dëm & dëm & dër & dën \\
\hline Accusative & dën & daz & die & die/diu \\
\hline Instrumental & & diu & & \\
\hline
\end{tabular}

Nübling (2005: 107) proposes another analysis of the grammaticalization path taking into account that the German definite article undergoes a further grammaticalization stage which is usually left behind by the research, namely the development into prepositional enclitics (im, zum, am, ans, etc.). This use of the definite article is not casual: on the one hand, not all article forms can be cliticised (for instance, die) and not all prepositions can be the basis for this kind of cliticization (gegenüber, trotz, etc.); on the other hand, there are contexts in which the position of the article does not depend on factors such as grammatical economy (a very significant element in grammaticalization paths), origin of the speaker, style, etc, but must obligatorily be attached to the preposition to avoid ungrammaticality: die Entwicklung vom (*von dem) Demonstrativ zum (*zu dem)

\footnotetext{
${ }^{26}$ In fact, the rise of the article in Old High German also had syntactic consequences, such as the postposition of the genitive article in contrast with its previous position before the noun.
} 
Artikel, sie wandert im (*in dem) Gebirge, and so on. The analysis she proposes, based on Himmelmann's view (1997: 23, based, in turn, on Greenberg 1978 and Lehmann 1982), can be summarized as follows:

Deictic particle + categorical noun $>$ demonstrative pronoun $>$ demonstrative determiner $>$ weakly demonstrative definite determiner $>$ definite article $>$ affixal article $>$ noun marker

\section{The Development of the Definite Article in Romance Languages}

As regards Romance languages, the rise of the definite article, category shared by the whole language family, has often been linked to the loss of the Latin case system. In fact, the presence/absence of the definite article is one of the most outstanding differences between Latin and Romance and "Latin grammarians frequently remarked on the lack of an equivalent of the Greek article in their own language" (Posner 1966: 126). Therefore, argues Posner, one of the suggestions which have been elaborated consists of the rise of the definite article in Christian Latin as a transfer from Greek, although early Latin translations of the Greek New Testament do not show any relevant consistency of the representation of the Greek article in Latin. Faingold (1993: 6) claims that in language history, as well as in creolization and other emergent systems, definite articles are not borrowed from the superstrate languages but are created anew from demonstratives. As in English and German, the definite article in Romance grammaticalized from a distal pronoun, namely Latin $I L L E$, which also constitutes the base of the distal demonstrative, reinforced by a preposed ECCE (= Behold!). The Classical Latin demonstratives were increasingly used as articles in Vulgar Latin from ca. 380 to 1150 , indicating a change of function 
of this grammatical category. The initially anaphoric article derived from a deictic pronoun indicating the spatial position of the referent, widening then its function to denote: 1 . unique nouns; 2 . abstracts; 3 . inalienable possession, becoming therefore more specific in semantic content and syntactic form and undergoing a shift from a "pointing" to a more expressive and subjective meaning. This kind of semantic shift is generally considered to be a striking characteristic of the early stages of grammaticalization: the demonstrative is initially used exclusively to attract the hearer's attention and assumes then a subjective, "affective" use. Interestingly, the demonstrative deictic reduction was the starting point of the grammaticalization of both object clitics and the definite article ${ }^{27}$. According to Epstein (1994), who considers in particular the case of French, the definite article in this language developed from expressive uses of the Latin demonstrative ILLE.

As insisted on by Vincent (1997: 154), the competition between Latin ILLE and IPSE (i.e. between two demonstratives bearing mainly anaphoric/distal and contrastive features, respectively) in the early grammaticalization stage in Late Latin is at the origin of the role played by ILLE as the item which actually grammaticalized. According to Selig (1992: 165), it was eventually ILLE that was grammaticalized because of contextual reasons: it could be used in more diverse contexts as compared to IPSE, whose meaning was limited to anaphoric uses. Considering the corpus she analyzed, she comes to the following conclusions: as regards ILLE, "Der Bereich der definiten Erstnennung ist die eigentliche Funktionsdomäne von ILLE in den analysierten Texten". For IPSE, on the other hand, "IPSE wird in fast allen hier analysierten Texten in erster Linie zur Kennzeichnung anaphorisch definiter NPs verwendet" (Selig, 1992: 153). Type frequency and generalization would be then the reasons

\footnotetext{
${ }^{27}$ The double evolution of the deictic seems to be due to the context: ill- with a verb yields a pronoun, ill- with a noun an article.
} 
why ILLE, developed into the definite article in French. In Old French, the masculine nominative article is etymologically related to the corresponding pronoun, although they are not formally identical, while in Present-Day French, where the definite article, just as in the other Romance languages, serves to distinguish between definite and indefinite NPs, the article forms are identical to the clitic object pronouns:

ILLI $>$ pronoun $i l$, article $l i$

Modern French clitic pronouns/articles: le, la, les

(Les filles sont allées jouer. Regarde-les!)

The Spanish forms el, la, los, las correspond to Vulgar Latin ILLE, ILLA which in turn derived from Classical Latin ILLE, ILLA, forms which consistently appear before the noun phrase. Interestingly enough, the Portuguese forms $o, a$, os, as correspond to a Vulgar Latin innovation derived from ILLE, ILLA, i.e. the article variant $e a$, $e o$, which seem to have developed from the accusative forms illa, illum and still do not display a completely separate semantic value article-demonstrative even though they often convey the same form, as we see in the following examples (Faingold 1993: 8, citing Bernard 1971: 37; 102):

(16) In ea ergo die et in ea hora, qua auertarent Persae aquam 'On the day and in the hour when the Persians diverted the water' (The Pilgrimage of Etheria ${ }^{28}$, from: Faingold 1993: 8)

Faingold also argues that this grammaticalization path can be explained in terms of discourse factors. Comparing Vulgar Latin

${ }^{28}$ Itinerarium Aetheriae, tr. by Clara di Zoppola, in: Attilio Agnoletto, Storia del cristianesimo, IPL, Milano, 1978. 
texts over different centuries, we can mark a diverse pragmatic use of these items: texts from the $4^{\text {th }}-6^{\text {th }}$ century show that Latin demonstratives are used to refer to noun phrases corresponding to objects which are prominent in the discourse; texts from the $8^{\text {th }}$ century already show a significant change in the use of demonstratives as they are also used to refer to noun phrases that are accessible to the speaker and the hearer; the further development, from the $12^{\text {th }}$ century to the modern usage in the Romance languages, shows that the definite article precedes those noun phrases which can simply be identified by the speaker and the hearer, regardless of whether they actually play a prominent role in the discourse.

Rumanian is the only modern Romance language displaying the use of an enclitic definite article (whilst the indefinite article appears in front of the noun phrase, just as in Swedish). In this language the enclitic article is clearly related to the inflected disjunctive pronoun (Posner 1966: 127):

Fem. mama ('the mother' = măma+ea)

Masc. fiul ('the son' $=f i u+e l$ )

A significant syntactic difference in the use of articlesdemonstrative pronouns which these languages have developed in their history (and still showing the Latin heritage) consists of the fact that in cases like the following in French an article can be used with the function of a demonstrative, which is not the case in Italian and in Rumanian, which needs both the article and the pronoun, as noted by Posner:

(17) Le livre blanc et le rouge ('The white book and the red one')

(18) ... e quello rosso 


\section{(19)... cel roșul}

Faingold (1993) identifies three main types of criteria as central for recognizing Romance definite articles as a result of the grammaticalization of Latin demonstratives: statistical criteria, which are concerned both with a synchronic and a diachronic increase in text frequency of the emergent article; structural criteria, for example the analysis of phonological weakening (phonetic shortening, e.g. Lat. illa $>$ Sp. la and loss of stress) and location, including pronominal and postnominal position of the Latin demonstrative (for instance, illa aqua 'the water' vs. epistolam ipsam 'the letter'); functional criteria, regarding the status of the NPs being preceded by a demonstrative (nouns which are prominent in the narration or which are "accessible" due to prior mention).

\section{The Absence of the Definite Article in Slavic Languages}

As is well-known, Baltic and Slavic languages (except for Bulgarian and Macedonian) lack a definite article. As we have seen, the rise of the article is often linked to the loss of morphological case marking which many languages underwent in different periods of their history. Even if in some languages articles are found in coincidence with the presence of case declinations, a correlation is definitely present between these two developments ${ }^{29}$, as Bulgarian and Macedonian are the only two languages in the family which

\footnotetext{
${ }^{29}$ From this point of view, it is interesting to consider Renzi's explanation (1992) of the logical order in which the two phenomena took place: 1 . The development of the article, marked by case; 2 . Loss of nominal inflections made possible by the new affix. According to Renzi's hypothesis, this was the order that languages like Bulgarian and Macedonian followed in their diachronic development, as they lost morphological case.
} 
have developed the article category, which is postponed or agglutinated, after the loss of morphological case. The case of Bulgarian and Macedonian represents a further confirmation of the development of the definite article from demonstratives, since this category in the two languages evolved out of the Old Slavic demonstrative pronoun *jb, *ja, *je ('this'), a form which disappeared from the spoken language by the $16^{\text {th }}$ century but was maintained in the literary language (Gebert 1996: 11). Gebert also claims that a striking characteristic of the Slavic languages which have not developed the definite article is the presence, attested in Old Slavic, of long and short forms of the adjective, which linguists generally define as definite and indefinite ${ }^{30}$, respectively, and are today still productive in Slavic languages. Long forms of the adjective are interestingly composed of the adjective and the demonstrative pronoun $* j b, * j a, * j e$, that, in turn, developed from the Indo-European deictic *-io and belongs to the same class as the Latin demonstrative is.

Heine and Kuteva $(2003,2005)$ propose that grammaticalization and contact-induced language change are not mutually exclusive and they may jointly conspire in triggering grammatical change.

Talking about areal convergence in grammaticalization processes, Giacalone Ramat (2008) draws on data from a recent study on the use of demonstrative pronouns in Czech, Sorbian and Slovenian (Trovesi 2004) to hypothesize that this category is undergoing a grammaticalization path in these languages. Giacalone Ramat and Trovesi's interesting assumption, diverging from - or at least offering new stimuli to - the classical theory on the origin of the article in Indo-European languages is that this development of ten, tón, $t a$ is taking place under the influence of German, since the German language played in history a significant cultural and political role in the areas where Czech, Sorbian and Slovenian are

\footnotetext{
${ }^{30}$ This definition depends on the fact that they express definiteness and indefiniteness.
} 
spoken. Heine and Kuteva's claim that the Sorbians simply replicated the article category having as a starting point the German article seems to be inadequate in that the category has not yet fully arisen in Sorbian and in the other Slavic languages in question, as the grammaticalization is still at an incipient stage; it is now arising in the mind of bilingual individuals.

\section{Conclusion}

In this paper I examined the concept of grammaticalization in all its facets (from a general to a more author-specific definition, from its implications in pragmatics to its role in the generative framework and to the studies which call into question the validity of the grammaticalization theory, etc.). I also analyzed the particular case of the grammaticalization of demonstrative pronouns into the definite article in crosslinguistc and diachronic perspective, focusing on English and German as representatives of the Germanic language family and mentioning the development or absence of this category in Romance and Slavic languages. The reasons generally linked to this kind of grammaticalization path are linked to the loss of morphological case marking in a certain stage of the development of the language. In the course of this development, demonstratives lose their deictic function and turn into formal markers of definiteness. Among the Indo-European languages, the grammatical category of the definite article is a common characteristic in the Germanic and in the Romance family, whereas Baltic and Slavic languages lack a definite article. The only exceptions in the latter case are Macedonian and Bulgarian, which developed a post-posed definite article after the loss of the morphological case system. There are also cases, in particular among the Slavic languages (Sorbian, Czech, Slovenian), which can be considered to be under way in their grammaticalization path demonstrative $>$ definite article. 
38 The Grammaticalization of Demonstratives: A Comparative Analysis

\section{References}

Aitchison, J. 2001. Language Change: Progress Or Decay? 3rd ed. Cambridge: Cambridge University Press.

Alexiadou, A., L. Haegeman \& M. Stavrou. 2007. Noun Phrase in the Generative Perspective (Studies in Generative Grammar 71). Berlin - New York: Mouton de Gruyter.

Allan, K. 2001. Natural Language Semantics. Oxford \& Malden: Blackwell Publishers.

Althaus P., H. Henne \& H.E. Wiegand. 1973. Lexikon der germanistischen Linguistik, Tübingen: Niemayer.

Anderson, S. R. 2005. Aspects of the Theory of Clitics Oxford: Oxford University Press.

Anttila, R. 1972. An Introduction to Historical and Comparative Linguistics. New York: McMillan.

Askedal, J. O. 2001. 'Oblique Subjects', Structural and Lexical Case

Marking: Some Thoughts on Case Assignment in North

Germanic and German. Faarlund, J. T. (ed.) Grammatical Relations in Change, 65-97.

Baugh, A. C. \& T. Cable. 1993. A History of the English Language. London: Routledge.

Beekes, R. 1995. Comparative Indo-European Linguistics: an Introduction. Amsterdam: John Benjamins.

Bianchi, V. 1999. Consequences of Antisymmetry: Headed Relative Clauses, Berlin New York: Mouton de Gruyter.

Bisang, W., N. Himmelmann \& B. Wiemer. 2004. What Makes Grammaticalization? A Look from its Fringes and its Components. Berlin New York: Mouton de Gruyter.

Booij, G., C. Lehmann \& J. Mugdan. 2000. Morphologie. Ein internationales Handbuch zur Flexion und Wortbildung. Berlin - New York: Mouton de Gruyter.

Braune, W. \& E. Ebbinghaus. 1994. Althochdeutsches Lesebuch, 17th ed. Paris: Niemeyer. 
Brinton, L. J. \& E. Traugott. 1995. Lexicalization and Language Change. Cambridge: Cambridge University Press.

Campbell, L. 1998. Historical Linguistics: An Introduction. Cambridge, MA: MIT Press.

_. 2001. What's Wrong with Grammaticalization? Language Sciences 23, 113-161.

Chambers, J. K. 1995. Sociolinguistic Theory: Linguistic Variation and its Social Significance, Oxford: Blackwell.

Cinque, G. \& G. Giusti. 1995. Advances in Roumanian Linguistics. Amsterdam: John Benjamins.

Crespo, E., J. De La Villa \& A. R. Revuelta. 2006. Word Classes and Related Topics in Ancient Greek: Proceedings of the Conference on 'Greek Syntax and Word Classes' Held in Madrid June 2003, Madrid: Peeters Publishers.

Cruttenden, A. \& D. Faber. 1991. The Accentuation of Prepositions. Journal of Pragmatics 15, 265-286.

Crystal, D. 1980. A First Dictionary of Linguistics and Phonetics. Boulder, CO: Westview Press.

Diessel, H. 1999. Demonstratives: Form, Function, and Grammaticalization. Amsterdam Philadelphia: John Benjamins.

. 1999. The Morphosyntax of Demonstratives in Synchrony and Diachrony. Linguistic Typology 3, 1-49.

Diessel, H. 2003. The Relationship Between Demonstratives and Interrogatives. Studies in Language 27, 581-602.

Diewald, G. 2006. Context Types in Grammaticalization as Constructions. Constructions 1-9, 2006. Available at URL $<\mathrm{http}$ ://www.constructions-online.de/articles/specvol1/>

Eckardt, R. 2008. Meaning Change in Grammaticalization: An Enquiry into Semantic Reanalysis. Oxford: Oxford University Press.

Einhauser, E. 1989. Die Junggrammatiker. Ein Problem für die Sprachwissenschaftsgeschichtsschreibung. Trier: Wissenschaftlicher Verlag. 
40 The Grammaticalization of Demonstratives: A Comparative Analysis

Epstein, R. 2001. The Meaning of Definite Articles in CrossLinguistic Perspective. In: Eniko Németh (ed.). Cognition in Language Use: Selected Papers from the $7^{\text {th }}$ International Pragmatics Conference, Antwerp: International Pragmatics Association, 174-189.

Faingold, E. 1993. The Development of the Definite Article from Latin to Spanish and Portuguese. Paper presented at the 1993 Annual Meeting of the Linguistic Society of America, Los Angeles, California. Jan. 1993.

Fillmore, C.J. 1988. The Mechanism of 'Construction Grammar', Proceedings of the Fourteenth Annual Meeting of the Berkley

Linguistic Society. Berkley: University of California Press. 3555.

Fischer, O, M. Norde \& H. Perridon. 2004. Up and down the Cline The Nature of Grammaticalization. Amsterdam: John Benjamins. Fortson, B. W. 2004. Indo-European Language and Culture. London: Blackwell Publishers.

Fox, A. 1995. Linguistic Reconstruction. An Introduction to Theory and Method. Oxford: Oxford University Press.

Gebert, L. 1996. Riflessioni sull'Articolo Mai Nato nelle Lingue Slave. In Bernacchio R. et al., Determinatezza e Indeterminatezza nelle Lingue Slave, Padova: Unipress.

Ghomeshi, J., I. Paul \& M. Wiltschko. 2009. Determiners: Universals and Variation. Amsterdam: John Benjamins.

Giacalone R., A. 2008. Areal Convergence in Grammaticalization Processes. In López-Couso, M. J. \& E. Seoane (eds.), Rethinking grammaticalization: New Perspectives for the TwentyFirst Century. Amsterdam - Philadelphia: John Benjamins.

Giusti, G. 1993. La Sintassi dei Determinanti. Padova: Unipress.

Giusti, G. 1999. The Functional Structure of Noun Phrases. A Bare Phrase Structure Approach. Working Papers in Linguistics 9, $105-160$.

Givón, T. 1979. On Understanding Grammar. New York: Academic 
Press.

Givón, T. 1991. Markedness in Grammar: Distributional, Communicative and Cognitive Correlates of Syntactic Structure. Studies in Language 15, 335-370.

Grice, H. P. 1975. Logic and Conversation. In Cole, P. \& J. Morgan, Syntax and Semantics. Speech Acts. New York: Academic Press. Greenberg, J. H. 1990. How Does a Language Acquire Gender Markers? In Denning, K. \& S. Kemmer. On Language: Selected Writings of Joseph H. Greenberg. Stanford: Stanford University Press.

Greenberg, J. H. 1991. The Last Stages of Grammatical Elements:

Contractive and Expansive Desemanticization, in Traugott and Heine, eds., Vol.1, Approaches to Grammaticalization, Amsterdam: John Benjamins.

Haegeman, L. 1997. The New Comparative Syntax. London: Longman.

Haider, H., S. Olsen \& S. Vikner. 1995. Studies in Comparative Syntax. Dordrecht: Kluwer Academic Publishers.

Halliday, M. 1961. Categories of the Theory of Grammar in Halliday(ed.) System and Function in Language. Oxford: Kress, 52-72.

Hammond, M. \& M. Noonan. 1988. Theoretical Morphology: Approaches in Modern Linguistics, San Diego: Academic Press. Harris, A. C. 2002. Endoclitics and the Origins of Udi Morphosyntax. Oxford: Oxford University Press.

Haspelmath, M. 1998. Does Grammaticalization Need Reanalysis? Studies in Language 22, 315-372.

Haspelmath, M. 1999. Why Is Grammaticalization Irreversible? Linguistics 37, 1043-1068.

Hawkins, J. A. 2004. Efficiency and Complexity in Grammars. Oxford: Oxford University Press.

Heine, B. \& M. Reh 1984. Grammaticalization and Reananalysis in African Languages. Hamburg: Buske. 
42 The Grammaticalization of Demonstratives: A Comparative Analysis

Heine, B. \& T. Kuteva. 2002. World Lexicon of Grammaticalization. Cambridge: Cambridge University Press.

Hopper, P. J. \& E. Traugott. 2003. Grammaticalization, 2nd ed. Cambridge: Cambridge University Press.

Heine, B. \& T. Kuteva. 2003. On Contact-induced Grammaticalization. Studies in Language 27, 529-272.

Heine, B. \& T. Kuteva. 2005. Language Contact and Grammatical Change. Cambridge: Cambridge University Press.

Himmelmann, N. P. 1997. Deiktikon, Artikel, Nominalphrase: Zur Emergenz syntaktischer Struktur. Tübingen: Niemeyer.

Hogg, R. \& D. Denison. 2008. A History of the English Language.

Cambridge: Cambridge University Press.

Hopper, P. \& E. Traugott. 2003. Grammaticalization, $2^{\text {nd }}$ ed. Cambridge: Cambridge University Press.

Humboldt, W. 1822. On the Origin of Grammatical forms and their Influence on the Development of Ideas. In: P. Lang. 1997. Essays on Language. Frankfurt am Main: Europäischer Verlag der Wissenschaften.

Jeffers, R. J. \& A. M. Zwicky. 1980. The Evolution of Clitics. In 1980. Papers from the 4th International Conference on Historical Linguistics. E. Traugott, R. LaBrum \& S. Shephard. (eds.) Amsterdam: John Benjamins.

Joseph, B. 2001. Is There Such a Thing as "Grammaticalization"? Language Sciences 23, 163-186.

Josipovici, G. 1971. The World and the Book: A Study of Modern Fiction. Stanford: Stanford University Press.

Jucker, A. H., G. Fritz \& F. Lebsanft. 1999. Historical Dialogue Analysis. Amsterdam: John Benjamins.

Juvonen, P. 2000. Grammaticalizing the Article - A Study of Definite Adnominal Determiners in a Genre of Spoken Finnish. Stockholm: Stockholm University.

Krug, M. G. 2000. Emerging English Modals. A Corpus-based Study of Grammaticalization. New York \& Berlin: Mouton de 
Gruyter.

Kuriłovicz, J. 1975. The Evolution of Grammatical Categories.

Esquisses Linguistiques II, 38-54.

Lane, G. S. 1961. On the Formation of the Indo-European Demonstrative. Language 37, 469-475.

Lass, R. 1997. Historical Linguistics and Language Change.

Cambridge: Cambridge University Press.

Leuschner, T., T. Mortelmans \& S. De Groodt. 2005.

Grammatikalisierung im Deutschen, Berlin: Mouton De Gruyter.

Lightfoot, D. 1999. The Development of Language: Acquisition, Change and Evolution. Oxford: Blackwell.

Lyons, C. 1999. Definiteness. Cambridge: Cambridge University Press.

Marouzeau, J. 1953. Lexique de la Terminologie Linguistique. Paris: Geuthner.

McMahon, A. 1994. Understanding Language Change. Cambridge: Cambridge University Press.

Meillet, A. 1912, L'Evolution des Formes Grammaticales. Scientia $12,384-400$.

Müller, H. H. \& A. Klinge 2008. Essays on Nominal Determination. Amsterdam Philadelphia: John Benjamins.

O'Neil, W. 1978. The Evolution of the Germanic Inflectional System: A Study of the Causes of Language Change. Orbis 27, 246-86.

Oniga, R. 2004. Il Latino. Breve introduzione linguistica. Milano: Franco Angeli.

Osawa, F. 2007. The Emergence of DP in the History of English: The Role of the Mysterious Genitive. In Historical Linguistics 2007. Selected Papers from the 18th International Conference on Historical Linguistics, M. Dufresne, F. Dupuis \& E. Vocaj. (eds.) Montréal, Québec, August 2007. Amsterdam: John Benjamins. 
44 The Grammaticalization of Demonstratives: A Comparative Analysis

Oubouzar, E. 1992. Zur Ausbildung des bestimmten Artikels im Althochdeutschen. In Y. Desportes (ed.) Althochdeutsch. Syntax und Semantik. Lyon, 71-87.

Parotté, W. \& R. Dirven. 1985. The Ubiquity of Metaphor. Amesterdam Studies in the Theory and History of Linguistic Science IV. Amsterdam: John Benjamins.

Philippi, J. 1997. The Rise of the Article in the Germanic Languages. In Parameters of Morphosyntactic Change, Van Kamenade, A. $\&$ N. Vincent. (eds.) Cambridge: Cambridge University Press, 62-93.

Posner, R. 1966. The Romance Languages. A Linguistic Introduction. New York: Doubleday.

Radden, G. \& K. U. Panther 2004. Studies in Linguistic Motivation. Cognitive Linguistics Research. Berlin New York: Mouton de Gruyter.

Ramat, P. 1987. Linguistic Typology. Berlin: Mouton de Gruyter.

Renzi, L. 1992. Le Développement de l'article en Roman. Revue Roumaine de Linguistique 2, 161-176.

Ringe, D. 2006. A Linguistic History of English. Volume I. From Proto-Indo-European to Proto-Germanic Oxford: Oxford University Press.

Rizzi, L. 1997. The Fine Structure of the Left Periphery. In: L. Haegemann (ed.), Elements of grammar. Dordrecht: Kluwer, 281-337.

Roberts, I. 1993. A Formal Account of Grammaticalization in the History of Romance Futures. Folia Linguistica Historica 13, 219-258.

Roberts, I. \& A. Roussou. 2003. Syntactic Change, A Minimalist Approach to Grammaticalization. Cambridge: Cambridge University Press.

Salmons, J. C. \& S. Dubenion-Smith 2007. Historical Linguistics 2005: Selected Papers from the 17th International Conference on Historical Linguistics, Amsterdam Philadelphia: John 
Benjamins.

Selig, M. 1992. Die Entwicklung der Nominaldeterminanten im Spätlatein. Script-Oralia 26, 238-260.

Sonderegger, S. 1979. Grundzüge Deutscher Sprachgeschichte. Diachronie des Sprachsystems. Bd. 1: Einführung, Genealogie, Konstanten. Berlin New York: Mouton de Gruyter.

Song, J. J. 2001. Linguistic Typology: Morphology and Syntax. Harlow and London: Longman.

Stark, E., E. Leiss \& W. Abraham. 2007. Nominal Determination:

Typology, Context Constraints, and Historical Emergence. Amsterdam: John Benjamins.

Swanton, M. 1996. The Anglo-Saxon Chronicles. London: J.M. Dent. Traugott, E. 1982. From Propositional to Textual to Expressive Meanings: Some Semantic-Pragmatic Aspects of Grammaticalization. In W.P. Lehmann \& Y. Malkiel. Perspectives on Historical Linguistics. Amsterdam: John Benjamins.

Traugott, E. 1995. Subjectification in Grammaticalisation. In: D.

Stein and S. Wright, Subjectivity and Subjectivisation. Cambridge: Cambridge University Press.

Traugott, E. \& R. Dasher. 2002. Regularity in Semantic Change. Cambridge: Cambridge University Press.

Trovesi, A. 2004. La genesi di articoli determinativi. Modalità di espressione della definitezza in ceco, serbo-lusaziano e sloveno. Pavia: Franco Angeli.

Tschirch, F. 1975. Geschichte der Deutschen Sprache. Berlin: Erich Schmidt Verlag.

Van Gelderen, E. 2000. A History of English Reflexive Pronouns: Person, Self, and Interpretability. Amsterdam: John Benjamins.

Van Gelderen, E. 2004. Grammaticalization as Economy. Amsterdam: John Benjamins.

Van Gelderen, E. 2006. A History of the English Language. Amsterdam - Philadelphia: John Benjamins.

Van Kamenade, A. \& N. Vincent. 1997. Parameters of Morpho- 
46 The Grammaticalization of Demonstratives: A Comparative Analysis

syntactic Change. Cambridge: Cambridge University Press.

Van Kemenade, A. 2000. Jespersen's Cycle Revisited: Formal Properties of Grammaticalization. In S. Pintzuk al. Diachronic Syntax. Models and Mechanisms Oxford: Oxford University Press.

Van Kemenade, A. \& B. Los. 2006. The Handbook of the History of English. London: Blackwell.

Von der Gabelentz, G. 1901. Die Sprachwissenschaft. Ihre Aufgaben, Methoden und bisherigen Ergebnisse. Leipzig: Tauchnitz.

Wanner, D. 1987. The Development of Romance Clitic Pronouns: From Latin to Old Romance. Berlin: Mouton de Gruyter.

Wood, J. 2007. Demonstratives and Possessives: From Old English to Present-Day English. In E. Stark, E. Leiss, A. Werner (eds.), Nominal Determination:Typology, Context Constraints, and Historical Emergence. Amsterdam: John Benjamins. 